\title{
Articles
}

\section{The Changing Nature of Law's Natural Person: The Impact of Emerging Technologies on the Legal Concept of the Person}

\author{
By Britta van Beers*
}

\begin{abstract}
This article discusses the legal concept of the person against the background of technological developments. Emerging technologies are offering radical ways to transform the biological and physical aspects of life. Several legal scholars claim that the technological artificialization of human life also calls for a more artificial, disembodied account of the natural person in law. According to them, the legal distinction between natural persons (human legal subjects) and artificial persons (non-human legal subjects, such as corporations) is becoming diluted and increasingly redundant. This article argues that, in an era of growing technological and postmodern disembodiment, the traditional legal distinction between natural and artificial persons remains important, albeit in a different form. An examination of the legal concept of the person in biomedical law suggests that law's category of the natural person still has its merits, not just despite these technological developments, but, remarkably enough, also because of them.
\end{abstract}

\footnotetext{
*Associate Professor, Faculty of Law, Department of Legal Theory, VU University Amsterdam, The Netherlands. Email: b.c.van.beers@vu.nl.
} 


\section{A. Introduction}

With the German legal philosopher Gustav Radbruch it could be said that: "[N]othing is as decisive for the style of a legal era as the conception of the person towards which it is oriented." ${ }^{1}$ Radbruch's remark underlines the vital importance of reflection on the question of what it means to be a person in law. Who is the addressee of legal norms, and how is this addressee connected to actual flesh-and-blood human beings?

The apparent simplicity of this basic question proves to be deceptive. Indeed, some of the great names in philosophy and jurisprudence, ranging from Hans Kelsen to Lon Fuller, and from John Dewey to Hannah Arendt, ${ }^{2}$ have struggled to come to an understanding of this elementary, yet puzzling notion of law. Moreover, the discussions among $19^{\text {th }}$ century legal scholars about the "endless problem of corporate personality"3-resulting in numerous publications and even competing schools of thought-illustrate the strange elusiveness of law's concept of the person.

Given this history, it is remarkable that until recently the legal notion of the person remained largely undertheorized within contemporary legal scholarship, ${ }^{4}$ especially among common law scholars. Indeed, within the common law world, the law of persons is not generally recognized as a separate field of study. ${ }^{5}$ Additionally, courts and scholars employ different meanings of law's person across different branches of law, seemingly without prior, systematic reflection on the nature of this legal category. ${ }^{6}$ The only constant seems to be the distinction between two types of legal persons: On the one hand, natural

\footnotetext{
${ }^{1}$ Gustav Radbruch, Der Mensch im Recht. Ausgewählte Vorträge und Aufsätze Über Grundfragen des Rechts 9 (1961) ("Nichts ist so entscheidend für den Stil eines Rechtszeitalters wie die Auffassung vom Menschen, an der es sich orientiert").

${ }^{2}$ See infra notes $43,51,60$, and 62.

${ }^{3}$ See Max Radin, The Endless Problem of Corporate Personality, 32 CoLum. L. ReV. 643 (1932).

${ }^{4}$ See David Fagundes, What We Talk About When We Talk About Persons: The Language of a Legal Fiction, 114 HARV. L. ReV. 1768 (2001); Ngaire Naffine, Who Are Law's Persons? From Cheshire Cats to Responsible Subjects, 66 MOD. L. Rev. 346 (2003); and Jessica Berg, Of Elephants and Embryos: A Proposed Framework for Legal Personhood, 59 HASTINGS L. J. 370 (2007).

${ }^{5}$ In many civil law countries, however, the law of persons is recognized as a special area of family law, with textbooks, monographs, and sometimes even heated scholarly debates on the subject.

${ }^{6}$ See Fagundes, supra note 4.
} 
persons, ${ }^{7}$ as human bearers of rights and duties are called in legal doctrine; and on the other hand, artificial persons ${ }^{8}$ such as corporations or public bodies.

This situation, however, is currently changing in two respects. First, a number of recent monographs ${ }^{9}$ and articles $^{10}$ on the issue of legal personality suggests a renewed interest among legal scholars in the matter. A recurring theme in these recent studies is the complex interplay between the legal concept of the person and the images of the human surfacing in new technological contexts.

Second, within this emerging body of scholarly literature, the legal distinction between natural and artificial persons is being thoroughly questioned. Recent technologies, such as medical biotechnology and artificial intelligence, are offering radical ways to transform the biological and physical aspects of life, thus challenging the natural outlines of the legal category of the person. In response to these developments, several legal scholars have claimed that this technological artificialization of human life also calls for a more artificial account of the natural person in law. According to them, the legal distinction between natural and artificial persons has lost its credibility in our postmodern and deeply technological society.

These recent attempts at deconstructing the natural/artificial divide in the law of persons raise the question as to how natural and artificial persons can be distinguished in the first place. Indeed, from a strictly legal perspective, natural and artificial persons are similar in many ways. Both can enter into contracts, incur debts, be sued, or own property. Moreover, despite its somewhat confusing designation as "natural," the natural person is clearly as much a construction of legal discourse as the artificial person is: It is the shape we take on when we enter the legal realm, leaving behind our flesh-and-blood selves, to be addressed as subjects of law. ${ }^{11}$

\footnotetext{
7 The term "natural person" is used throughout this article in a strictly legal sense and should not be confused with actual flesh-and-blood human beings.

${ }^{8}$ Even though the terms "juristic" or "juridical person" are also common, "artificial person" is used here because the main theme of this article concerns the artificialization of natural persons and human beings.

9 See, e.g., Alain SUPIOt, Homo Juridicus: ON the ANTHropological Function of the LaW (Saskia Brown trans., 2007); Ngaire Naffine, LaW's Meaning of Life: Philosophy, Religion, DarWin and the Legal Person (2009); Sheryl Hamilton, Impersonations: Troubling the Person in Law and Culture (2010); Dorien Pessers, The Symbolic Meaning of Legal Subjectivity, in SYMBolic LegISLATION THEORY AND NeW DEVELOPMENTS IN BIOLAW (Bart van Klink, Britta van Beers \& Lonneke Poort eds., 2016); Britta van Beers, Persoon en lichaAm in het Recht. Menselijke WaARdigheid en ZelfBeschiKking In het TiJdPerk VAN de Medische Biotechnologie (2009); Florence Bellivier, Le Droit des Personnes (2015); LA PeRSONNALITÉ JURIDIQUe (Xavier Bioy ed., 2013).

${ }^{10}$ See infra note 11.

${ }^{11}$ See 1 William BLACKSTONe, COMmentaries ON THE LAWS OF ENGLAND 123 (1765). From that perspective, Blackstone's explanation of the difference between natural and artificial persons is misleading: "Persons also are divided by the law into either natural persons, or artificial. Natural persons are such as the God of nature formed us; artificial
} 
Yet certain important differences in legal design and status remain. Unlike natural persons, artificial persons cannot, for instance, have parental rights, be given jail sentences, or vote. Furthermore, while corporate bodies are formed and dissolved upon resolution, the beginning and ending of natural personality coincide with the biological events of birth and death. More generally, the artificial person is characterized by a high degree of plasticity. Indeed, if a corporation can be described as "the mere creature of law,"12 it is a very imaginative creature: An invisible, intangible, and immortal entity, ${ }^{13}$ "without body and without soul,"14 which can change identity in a matter of hours, and amputate parts from itself to grow these into new legal life forms.

These basic differences between natural and artificial persons suggest a preliminary answer to the question of what makes the natural person natural in the first place. In certain contexts, the concept of natural personality presupposes an embodied subject, as in the case of jail sentences and the semi-organic outlines of natural personality; and, in others, a human subject, as in the case of parental rights or the right to vote. In that sense, natural personality is indeed premised on a certain nature, even if that nature is legally constructed.

Nonetheless, these naturalistic underpinnings of law's natural person have become contested. What can the terms "embodied" and "human" mean in a postmodern society, in which common views of the human body and humanity are increasingly being challenged, including on a legal level? More generally, appeals to naturalness or nature are increasingly mistrusted in legal and political decision-making on technological issues. A striking illustration is the outcome of a recent report from the Nuffield Council on Bioethics on the meaning of the term "naturalness" in bioethical debates. One of the report's main conclusions is "that effective communication on the ethics of science, technology, and medicine may be hindered, rather than helped, by appeals to naturalness." 15

All of these developments make the natural person less self-evident and, in that sense, less "natural" than ever. Has the legal category of the natural person had its best time, and can the artificial person take its place? This article argues that in an era of increasing

\footnotetext{
are such as are created and devised by human laws for the purposes of society and government, which are called corporations or bodies politic." Id.

12 See Trustees of Dartmouth College v. Woodward, 17 US 518 (1819).

${ }^{13}$ Because of its defining asset of perpetual succession.

${ }^{14}$ A.W. Machen, Corporate Personality, 24 HARV. L. REV. 253 (1911).

15 Nuffield Council on Bioethics, Ideas about Naturalness in Public and Political Debates about Science, Technology and Medicine, $106 \quad$ (November 2015), http://nuffieldbioethics.org/wpcontent/uploads/NCOB_unnatural_booklet.pdf.
} 
technological and postmodern disembodiment, the traditional legal distinction between natural and artificial persons remains important, albeit in a different form. An examination of the legal concept of the person, as it is emerging in the field of biomedical law ("biolaw"), suggests that the category of the natural person, even if it is going through a period of rapid change, is still thriving. It thrives not only despite technological developments, but, remarkably enough, also because of them. More importantly, the artificialization of the natural person has several problematic consequences for the regulation of biomedical developments which will be discussed in this article.

The line of reasoning is as follows. Section B considers to what extent the biological boundaries by which the natural person has been traditionally demarcated have come under pressure from recent and emerging medical technologies. This is followed by an examination of the scholarly proposals to deconstruct and "denaturalize" the legal concept of the natural person in answer to these developments. These scholars defend a strictly legal and highly technical understanding of the person which can be traced back to Roman law. Section C identifies three characteristics of this artificialistic Roman concept of the legal person, which are of specific significance for the regulation of biomedical technologies. In the Roman tradition, the natural person is: (1) a disembodied entity, (2) characterized by fictional temporal boundaries, and (3) reflecting a role that can be rewritten at will. As will be argued, these three characteristics represent three possible types of artificialization of the legal concept of the natural person which resonate in current debates on biomedical regulation: (1) a disembodiment, (2) fictionalization, and (3) fragmentation of the legal category of the natural person. Sections D, E and F draw out the problematic consequences of each of these three forms in the regulation of biomedical technologies. This analysis leads to the conclusion in Section $G$ that a strictly legal-technical and artificialistic account of the person cannot do justice to the complex interplay between law and the biological dimensions of human life within the currently emerging body of biolaw.

\section{B. Law's Natural Person: Artificial by Nature?}

\section{The Natural Boundaries of Natural Persons}

Even if the category of the natural person is, in essence, a legal construction, the most basic biological facts of life, such as birth, death, and reproduction, have also all left their mark on it, as illustrated by areas of law such as family law, inheritance law, the law of birth registration, and burial law. Thus, natural persons are traditionally characterized, unlike artificial persons, by several biological traits. The following five are the most prominent:

(1) All natural persons belong to the human species;

(2) The beginning of natural personality coincides with birth;

(3) The ending of natural personality coincides with death; 
(4) Natural persons are born out of a relationship between two persons of the opposite sex;

(5) Natural persons are either male or female.

Additionally, the major influence of human rights discourse and its naturalistic understanding of the legal person have served to reinforce the distinction between natural and artificial persons. In many contemporary legal contexts, therefore, law's person does not function as a merely legal-technical construction, comparable to the artificial person, but often also presupposes a certain vision of human beings.

This dogmatic distinction between natural and artificial persons, however, is coming under pressure from two directions. On the one hand, the rights of artificial persons are expanding to include rights that were formerly attributed exclusively to natural persons. In this process, artificial persons are, to a certain extent, being humanized and naturalized. A striking example is the European Court of Human Rights' recognition of corporations as holders of certain human rights. ${ }^{16}$

On the other hand, a tendency towards the disembodiment and artificialization of the natural person can be discerned. In a way, the natural person seems to be hemorrhaging into the artificial person by losing elements of its naturalistic aura and thus increasingly resembling the artificial person. Interestingly, where artificial personality was originally thought of as a derivative of natural personality, the natural person is now adopting certain traits of the artificial person. Indeed, all the five naturalistic premises of the natural person mentioned above seem either to be dissolving or to become contested.

\section{The Technological Contestation of the Natural Person's Natural Boundaries}

Each of these premises have been challenged in their own ways. As to Premise One (the requirement of membership of the human species for conferral of natural personality), an increasing number of scholars and activists are now arguing that the legal circle of persons should be widened to include other forms of life, such as certain animals or forms of artificial intelligence. On a more tangible level, the boundaries between human and animal are also blurring in biomedical settings through, for example, the creation of humananimal "cybrids." 17

\footnotetext{
16 See Marius Emberland, The Human Rights of Companies: Exploring the Structure of ECHR Protection (2006); Anna Grear, Human Rights - Human Bodies? Some Reflections on Corporate Human Rights Distortion, the Legal Subject, Embodiment and Human Rights Theory, 17 L. AND CRITIQUE 171 (2006); Anna Grear, Challenging Corporate 'Humanity': Legal Disembodiment, Embodiment and Human Rights, 7:3 HuM. RTS. L. REV. 511 (2007); Anat Scolnicov, Lifelike and Lifeless in Law: Do Corporations Have Human Rights?, IN UNIVERSITY OF CAMBRIDGE FACULTY OF LAW LEGAL STUDIES RESEARCH PAPER SERIES 13/2013 (2013), http://ssrn.com/abstract=2268537.

17 See HFEA statement on licensing of applications to carry out research using human-animal cytoplasmic hybrid embryos, http://www.hfea.gov.uk/418.html. In 2008, the UK Human Fertilisation and Embryology Authority (HFEA) granted the first licenses to create these hybrids.
} 
Within the domain of Premise Two, the emergence of assisted reproductive technologies ("ARTs") has put the protection of future children on the legal-political agenda. No longer is this question limited to the status of prenatal life, such as in debates on abortion or the use of human embryonic stem cells. Instead, recent discussions have extended to the question of what we owe to children born from technological settings, and to what extent their projected interests justify intervening in prospective parents' reproductive freedoms. ${ }^{18}$ Indeed, the welfare of future children has become one of the central principles in the law and ethics of assisted reproduction. ${ }^{19}$

The ending of personality, Premise Three, has been subject to vigorous legal and ethical debates since death became part of new medical practices. The best-known example is that of organ donation after brain death; however, other medical procedures, such as controlled organ donation after respiratory death ${ }^{20}$ and continuous deep sedation at the end of life, ${ }^{21}$ have more recently also elicited debate.

Until recently, Premise Four-legal parenthood-was largely modeled on a biological understanding of parentage, with the major exception of adoption. In response, however, to the new types of family formation that have emerged within the context of ARTs, it has now become legally possible in a number of countries for a partner in a same-sex relationship to be registered as the second parent of a child conceived through ARTs, without that partner having to go through an adoption procedure. ${ }^{22}$ Moreover, the legal possibility of having three or four legal parents is currently being discussed in various countries and has recently even been introduced in several legal systems. ${ }^{23}$ Also, the

\footnotetext{
18 In the UK, both the Congenital Disabilities Act 1976, especially Section 1A, and the Human Fertilisation and Embryology Act 1990 ("HFE Act"), especially Section 13(5), refer to the welfare and protection of children born from ARTs. For a recent discussion of the complexities surrounding this legal guideline, see Sally Sheldon, Ellie Lee \& Jan Macvarish, 'Supportive Parenting', Responsibility and Regulation: The Welfare Assessment under the Reformed Human Fertilisation and Embryology Act (1990), 78 MOD. L. REV. 461 (2015).

${ }^{19}$ See, e.g., G. Pennings, G. de Wert, F. Shenfield, J. Cohen, B. Tarlatzis, \& P. Devroey, ESHRE Task Force on Ethics and Law: The Welfare of the Child in Medically Assisted Reproduction, 22 HUM. REPRODUCTION 2585 (2007).

${ }^{20}$ See Seema K. Shah \& Frank G. Miller, Can We Handle the Truth? Legal Fictions in the Determination of Death, 36 AM. J. L. \& MED. 540-85 (2010)

${ }^{21}$ See, e.g., Kasper Raus, Sigrid Sterckx \& Freddy Mortier, Continuous Deep Sedation at the End of Life and the Natural Death Hypothesis, 26(6) BIOETHICS 329 (2012).

22 See, e.g., Human Fertilisation and Embryology Act 2008 c. 2 (Eng.); see Wet Lesbisch Ouderschap 1 April 2014 (Neth.); see Dorien Pessers, De Terugkeer van de Bastaard, 88 NeDERLANDS JURISTENBLAD 2595-96 (2013) (a critical analysis of the Dutch act).

${ }^{23}$ In British Columbia (Canada) and California (USA), it has become possible to have three legal parents. See Patricia Cassidy, Canada: Three Parents Listed on Baby's Birth Certificate, BIONEWs (Feb. 17, 2014), http://www.bionews.org.uk/page_396795.asp; see also Patrick McGreevy \& Melanie Mason, Brown Signs Bill to
} 
creation of what has been called "three-parent babies" could be seen as a more technological refutation of the traditional legal model of two parents, even if the resulting child will be genetically related to the second mother to only a minimal extent. ${ }^{24}$

Lastly, the legal distinction between male and female, Premise Five, is no longer selfevident. The medical and social recognition of transsexuality and intersexuality has led to a renegotiation of the legal construction of gender. A clear indication of this is the European Court of Human Rights' 2003 ruling that the right to a private life includes the right of postoperative transsexuals to have their new gender identities recognized in official documents and birth registries. ${ }^{25}$ Furthermore, until recently, many countries allowed recognition of a new gender identity only after operations for gender reassignment and irreversible sterilization. $^{26}$ In an increasing number of legal systems, however, these invasive requirements are now being abandoned. ${ }^{27}$

\section{From the Artificialization of Human Life Towards the Artificialization of Law's Natural Person?}

In each of the aforementioned examples, technology plays an important role in the reassessment of the natural person's naturalistic premises. All these examples suggest that the technological artificialization of human life is resulting in a corresponding artificialization of law's natural person. Indeed, emerging technologies, such as medical biotechnology and cognitive sciences, endorse a view of the human body, human life, and human nature as objects that can be redesigned, updated, and improved.

This biogenetic approach to human life has led to intense philosophical debates on the relationship between human nature and technology. How far can we push the artificialization of human nature, human reproduction, and human evolution, before they cease to be human at all? Or are technology and artificiality part of what makes us human,

Allow Children to Have More than Two Legal Parents, LoS ANgeles TIMES (Oct. 4, 2013), http://articles.latimes.com/2013/oct/04/local/la-me-brown-bills-parents-20131005.

${ }^{24}$ The United Kingdom is the first nation worldwide to allow this technology. See H. Devlin, Britain's House of Lords approves conception of three-person babies, The Guardian (Feb. 24, 2015), http://www.theguardian.com/politics/2015/feb/24/uk-house-of-lords-approves-conception-of-three-personbabies.

${ }^{25}$ Christine Goodwin v. United Kingdom, App. No. 28957/95 (11 July 2002), http://hudoc.echr.coe.int/.

26 According to Transgender Europe, 21 European countries in 2014 still, for example, required transgender people to undergo sterilization before their new gender identity could be legally recognized. See Trans Rights Euro Map, 2014, http://www.tgeu.org/sites/default/files/Trans_Map_Index_2014.pdf.

27 For an overview of the European situation regarding the human rights of transgender people, see Amnesty International, The State Decides Who I Am: Lack of Legal Gender Recognition for Transgender People in Europe (Feb. 4, 2014). 
and has human enhancement in that sense only radicalized the ways in which we have always been "artificial by nature," in the seminal words of German philosopher Helmuth Plessner ${ }^{28}$

These questions resonate on a legal theoretical level through renewed reflection on the nature of law's natural persons. Do biomedical developments lead to a denaturalization or even dehumanization of law's natural person? Or rather, should it be said that the legal concept of the natural person has, in essence, always been "artificial by nature," and that biomedical developments have only served to unveil that artificial nature?

Evidently, techno-enthusiasts, "transhumanists," 29 and advocates of "robot rights," will answer this last question in the affirmative. Less obvious is that several legal scholarswho have written extensively on the legal concept of the person-have recently joined this group by arguing for a further and more deliberate denaturalization and artificialization of the natural person.

Ngaire Naffine, for instance, whose comprehensive studies ${ }^{30}$ of common law's person have been of enormous value to this field, proposes to "liberate the legal person" from its naturalistic confines. To her, the merits of a more artificial concept of the person are that it "allows for multiple legal identities, so that the one entity can assume different legal natures depending on her circumstances and her place in a given set of relations." 31 Following Naffine, Sheryl Hamilton finds "the greatest intellectual and social potential" in the artificialistic conception of personality as it offers "a malleable, mobile concept, thus permitting subjects to morph into other identities."32 Jessica Berg, in turn, proposes extending the scope of the legal concept of artificial personality to include fetal, animal, and artificial forms of life in law. ${ }^{33}$ Anna Grear argues that artificial personality is better able to "respond to the complexities, mutations, hybridities and multiplicities confronting law in the twenty-first century," including biotechnological developments and the emergence of transhumanism. ${ }^{34}$ Lastly, according to French legal scholar Marcela lacub,

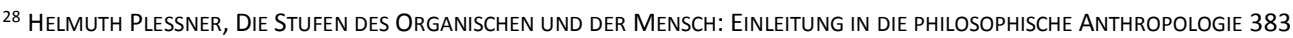
(1981).

29 Transhumanist philosophers, such as Nick Bostrom, Julian Savulescu and John Harris, advocate altering the human condition through human enhancement technologies, such as artificial intelligence, nanotechnology and biotechnology.

${ }^{30}$ See supra note 9, for her monograph Law's Meaning of Life, which builds on earlier work.

31 Ngaire Naffine, Review Essay: Liberating the Legal Person, 26 CANADIAN J. L. \& SOC'y 202 (2011).

32 HAMILTON, supra note 9, 20-21

${ }^{33}$ Berg, supra note 4.

${ }^{34}$ Anna Grear, Law's Entities: Complexity, Plasticity and Justice, 4 JURIS. 101 (2013).
} 
any legal limit to human enhancement that is based on human dignity or human nature is at odds with the inherently constructed nature of law's concept of the person. ${ }^{35}$

These authors, each in their own way, propose distilling the artificialistic aspects of the legal person and bringing them to fruition. To them, the complexities of life in a postmodern society-in which the categorical distinctions between person and thing, alive and dead, human and animal, male and female, and natural and artificial are being contested in various ways-require recognizing the "multiplicity and fluidity of legal identity." ${ }^{36}$ Indeed, their description of the legal person as "mutable and fluid," ${ }^{37}$ "chimeric," ${ }^{38}$ and "highly plastic" 39 could equally apply to the artificial humans who feature in the futuristic scenarios of techno-optimists and transhumanists. From that perspective, a strictly legal-technical understanding of the person would seem the best candidate. Within this artificialistic approach, there are no limits to the possibilities of legal personification, only the limits of lawyers' imagination.

These recent claims raise the question of what the exact relationship is between the technological artificiality of enhanced human beings on the one hand, and the legal artificiality of legal personality on the other. Should the legal concept of the natural person make place for the artificial person to keep up with the technological artificialization of human life?

In order to come to a critical discussion of these claims, first a better understanding of the artificialistic concept of the legal person is needed. The following section traces the artificialistic tradition back to Roman law: the legal person as persona. Three characteristics of persona are identified, which can also be recognized in current biolaw debates.

\section{Persona: The Natural Person as a Legal-Technical Fiction}

\section{The History of Legal Personality as a Dialectical Process Between Nature and Artifact}

It is not the first time in the history of the legal person that its boundaries have been subjected to vigorous renegotiation. In fact, the current wave of artificialization can be

\footnotetext{
${ }^{35}$ Marcela Iacub, le Crime Était Presque Sexuel (2002); Marcela Iacub, Penser les Droits de la Naissance (2002).

${ }^{36}$ Ngaire Naffine, Our Legal Lives as Men, Women and Persons, 21 LegAL Stud. 642 (2004).

${ }^{37}$ NAFFINE, supra note 9 , at 45 .

${ }^{38}$ Yan Thomas, Le Sujet de Droit, la Personne et la Nature: Sur la Critique Contemporaine du Sujet de Droit, LE DÉBAT 106 (1998).

${ }^{39}$ Grear, supra note 34 .
} 
regarded as the latest manifestation of an ongoing dialectical evolution of the legal concept of the person. The main question underlying these dialectics concerns the extent to which legal persons can be understood as a reflection of real-life, flesh-and-blood human beings, or rather as disembodied and strictly legal-technical abstractions. The resulting tension can be described in various terms, such as the contrast between realistic and nominalistic conceptions of the person, ${ }^{40}$ between legal naturalism and legal artificialism; ${ }^{41}$ or between metaphysical and metaphorical understandings of legal personality. ${ }^{42}$

Whichever terms are used, both conceptions have left their mark on current approaches to the legal person. Throughout its "chameleon-like change"43 the legal person has gone through alternating currents of artificialization and naturalization. For example, there is general agreement that the artificialistic components of legal personality largely date back to Roman law. ${ }^{44}$ From Byzantine law on, the growing influence of the view of man as imago dei (the image of god) and as a unity of body and soul led to gradual domestication of Roman law's imaginative approaches to persona. Indeed, as legal historian Jan Lokin writes, "there is no area of law in which the influence of Christian doctrine was so great as in the law of persons." ${ }^{\prime 4}$ A more recent example is the way in which the rise of legal positivism contributed to a strictly legal-technical understanding of the person. This development stagnated when the inherent human dignity of man and his inalienable human rights were invoked in post-war human rights discourse as a naturalistic safeguard against systematic legal depersonalization of individuals in society, such as occurred in the Third Reich.

Yet through most of its reincarnations over time, the legal person remained a "curious mixture of physical reality and abstraction," ${ }^{46}$ "a messy imbrication" 47 of both traditions. Various naturalistic and legal-technical views on personhood followed one after the other,

\footnotetext{
40 David Deroussin, Personnes, Choses, Corps, in Le CorPS et Ses RePrésentations 79 (Emmanuel Dockès and Gilles Lhuilier eds., 2001).

${ }^{41}$ Yan Thomas, Le Sujet Concret et Sa Personne. Essai d'Histoire Juridique Rétrospective, in DU DROIT DE NE PAS Naître. À Propos de L'Affaire Perruche (Olivier Cayla and Yan Thomas eds., 2002) 88-170; lacub, supra note 35.

42 See infra Section C.II.

${ }^{43}$ John Dewey, The Historic Background of Corporate Legal Personality, 35 YALE L.J. 658 (1926).

44 Richard Tur, The "Person" in Law, in Persons And Personality (A. Peacocke and G. Gillett eds., 1987) 123); Thomas, supra note 41; Deroussin, supra note 40.

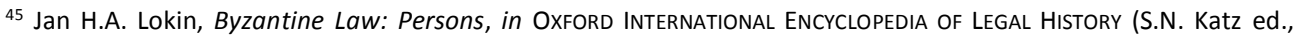
2009).

46 Thomas, supra note 41 , at 145.

${ }^{47}$ Hamilton, supra note 9, at 13.
} 
without later concepts completely replacing older ones. Consequently, within our contemporary understanding of the legal person, "almost all concepts have persisted side by side in a confused intermixture," ${ }^{48}$ as the American pragmatist philosopher John Dewey writes.

To add to the confusion, judges and legal scholars have continued to use both conceptions inconsistently and randomly, without making their underlying choices explicit. As Fagundes concludes from his elaborate analysis of the American law of persons: "Courts have not been able to distinguish cleanly between these two points of view, alternately treating the issue of personhood as a commonsense determination of what is human or as a formal legal fiction unrelated to biological conceptions of humanity." ${ }^{49}$ What is clear, however, is that the latter position, which portrays legal personality as a legal-technical fiction, is currently becoming more dominant within legal doctrine.

\section{The Natural Person as a Legal Fiction: From Legal Metaphysics to Legal Metaphors}

The aforementioned authors, who propagate an artificialistic account of the legal person in answer to technological developments, tend to depict the legal person as a legal fiction. In their view, the legal concept of the person has no metaphysical aspirations whatsoever. Naffine, for example, eloquently describes her own position as follows:

Legal personification, I suggest, is not best understood as a metaphysical exercise in working out the meaning of life-or, more particularly, what it is to be a person. Jurists are not metaphysicians.... Rather, the legal person is better regarded as and deployed as a legal fiction that can be flexibly adapted to a wide variety of beings and things .... ${ }^{50}$

Undoubtedly, some of the fictional dimensions of law's concept of the person are inevitable and even necessary. First, if the person can be regarded as an allocation point (Zurechnungspunkt) for rights and duties, to borrow Hans Kelsen's terminology, ${ }^{51}$ the natural person cannot but offer a highly generalized and abstract account of human beings. Moreover, a certain level of abstraction of legal personality is necessary in order to

\footnotetext{
${ }^{48}$ Dewey, supra note 43, at 658.

${ }^{49}$ Fagundes, supra note 4, at 1745.

${ }^{50}$ Naffine, supra note 30 , at 201

${ }^{51}$ More precisely: "Der gemeinsame Zurechnungspunkt für die als Pflichten und Rechte normierten Tatbestände menschlichen Verhaltens." See HANS KeLSEN, ReINE ReCHTSLeHRE 53 (Erste Auflage, 1934).
} 
achieve equality before the $\operatorname{law}^{52}$ and to protect against intrusions by the state in the personal lives of its citizens. ${ }^{53}$

As a result, the law's account of the person is characterized by certain peculiarities that distinguish it from commonplace understandings of the person. The French legal scholar Maurice Hauriou captures the fictional and even mysterious nature of homo juridicus ${ }^{54}$ well in the following, oft-quoted words: "Individual legal personality appears to us as continuous and self-identical; it emerges at the same time as the individual and is immediately constituted; it remains unchanged throughout its existence and unfailingly subtends unchanging legal situations; it is watchful when Man sleeps, and remains sane when Man loses his reason." ${ }^{55}$

Indeed, when lawyers talk about persons, they seem to talk about a different species than flesh-and-blood human beings. ${ }^{56}$ This can explain why nominalist approaches to legal personality abound within the literature on the subject. Dewey, for example, commences his influential article on the person in law with the observation that "person signifies what law makes it signify." ${ }^{157}$ In this vein, legal scholars often underline the difference between the legal-technical understanding of the word "person," and actual human beings. ${ }^{58}$ Many argue that there is no essential legal difference between the artificial personality of corporations, and the personality which befalls us naturally at birth. To them, natural persons are equally artificial creatures, as much disconnected from physical reality as the artificial person.

From this perspective, it seems unfortunate that the term "person," with all its connotations from everyday speech, is used to designate what is in fact a bundle of rights and duties, as Kelsen writes. ${ }^{59}$ According to this line of thinking, it is better to regard the legal term "person" as a metaphor. ${ }^{60}$ The Roman etymology of the word persona can be

\footnotetext{
${ }^{52}$ In this sense, see Naffine, supra note 36 , at 623.

${ }^{53}$ In this sense, see Jacques Ellul, Sur l'Artificialité du Droit et le Droit d'Exception, 8 ARCHIVES DE PHILOSOPHIE DE DROIT 26 (1963).

${ }^{54}$ SUPIOT, supra note 9.

${ }^{55} / d$. at 15.

${ }^{56}$ See Fagundes, supra note 4.

57 Dewey, supra note 43, at 655.

${ }^{58}$ See, e.g., J.C. GRAY, The NATURE AND SOURCES OF LAW 27 (1909).

${ }^{59}$ See Hans Kelsen, Pure Theory of Law 172 (2nd ed. 1967); B. Smith, Legal Personality, 37 Yale L.J. 293 (1928).

${ }^{60}$ Lon L. Fuller, Legal Fictions 25 U. ILL. L. Rev. 363, 373 (1930). In similar vein, see Fagundes, supra note 4; Naffine, supra note 30; Hamilton, supra note 9.
} 
used in support of this view. As is frequently mentioned in academic literature on the subject, persona originally stood for the mask that actors wore in Roman theatre. Thus, "the term's application to human beings was at first metaphorical," as Lon Fuller writes in one of his famous articles on legal fictions. ${ }^{61}$

\section{The Roman Roots of Persona}

As already mentioned, it is generally agreed that the "metaphorical" and artificialistic understanding of the legal person can be found in its purest form in Roman law. ${ }^{62} \mathrm{~A}$ brief examination of the meaning of legal personality in Roman law is therefore useful to draw out several remarkable characteristics of the artificialistic conception of legal personality.

Persona in Roman law initially referred to roles that one performed in particular legal contexts. ${ }^{63}$ In this sense, one individual could simultaneously sustain various personae. Depending on the legal and social situation one was in, one could play the legal role of paterfamilias, creditor, owner, employer, and so on. Conversely, in certain circumstances two persons were regarded in law as one persona. ${ }^{64}$ It is clear from this characterization that legal personality in this period did not aspire to have any metaphysical connotations with the human individual.

Instead, personality in this period is closely connected with the different statuses that could be distinguished within Roman society. The roles one could play depended on the social groups of which one was part, and on the statuses that one acquired or lost throughout one's life. ${ }^{65}$ More specifically, one's position was affected by three factors: status libertatis (all men are free or slave), status civitatis (all free men are citizens or aliens), and status familiae (all citizens are either paterfamilias or filiusfamilias). Together these assets formed one's caput. A capitis deminutio, or diminishing of personality, could occur when one of these assets changed. ${ }^{66}$ According to Richard Tur, the consequence of a diminution in status was that a new person took the place of the old person. Accordingly,

\footnotetext{
${ }^{61}$ Fuller, supra note 60 , at 377.

62 Thomas, supra note 38; Thomas, supra note 41; Giorgio Agamben, Identity without the Person, in NUDITIES 4654 (Giorgio Agamben, 2010); Tur, supra note 44; HANNAH ARENDT, ON REVOLUTION 102-03 (1966). For a different view, see John Austin, Lectures on JURISPRUdenCE: OR THE PHILOSOPHY Of PoSitive LAW 348 (1885).

${ }^{63}$ Tur, supra note 44; Thomas (2002), supra note 41; Deroussin, supra note 40; AUsTIN, supra note 62.

${ }^{64}$ Deroussin, supra note 40 , at 81 ; Thomas (2002), supra note 41 , at 126-27.

${ }^{65}$ Deroussin, id.; Tur, supra note 44, at 117; Thomas (2002), supra note 41, at 127.

${ }^{66}$ Tur, supra note 44, at 117; P.J. du Plessis, Roman Law: Persons, in OXford INTERnATIONAL ENCYCLOPEDIA OF LegaL HISTORY (S.N. Katz ed., 2009).
} 
"Romans could have a series of different legal lives, through the loss or acquisition of particular statuses." 67

From the fifth and sixth centuries onwards, persona no longer stood for the various legal roles an individual could have, nor for one's resulting status, but rather became synonymous with the capacity to play these roles on the stage of the law. ${ }^{68}$ It can be said that, from then on, persona became the legal counterpart of the individual, and that one could speak in terms of either having or not having legal personality (personam habere or non habere). Nevertheless, the flesh-and-blood individual still did not enter the theatre of law, with the most striking illustration of this being that legal personality functioned as a mechanism to include or exclude individuals in or from the legal order. Indeed, the legal status of slaves exemplifies how, in Roman law, not all human beings were equally endowed with legal personality.

As this overview shows, law's person was subject to change from its very beginning. Persona morphed from mask to legal role, to status, to legal capacity. ${ }^{69}$ Yet throughout these metaphorical shifts, the radical disjunction between persona and homo-between person and human being-persisted within Roman law. ${ }^{70}$ The concept of legal personality has been evolving since its Roman origins and will undoubtedly continue to do so. If the artificiality of Roman law's person still seems quite audacious to modern minds, that is because the concept has lost many of its nominalist edges over time and has gone through several waves of naturalization. There are indications, however, that the Roman concept of the person is about to make a come-back on the "stage" of law. As explained above, technological developments have prompted several scholars to go back to the Roman roots of the legal person, and propagate a renewed disjunction between persona and homo. Are these authors right in claiming that the artificialistic account of personality is better equipped to deal with the technological and postmodern interrogations of the human and the physical?

Although there are undoubtedly certain advantages to an artificialistic concept of the legal person over a naturalistic one, this article's central thesis is that a purely artificialistic concept shows several important shortcomings in the legal regulation of biomedical technologies. To substantiate that position, the following sub-section identifies three characteristics of the Roman concept of legal personality, which can also be recognized in contemporary debates on medical biotechnology.

\footnotetext{
${ }^{67}$ Tur, supra note 44 , at 117.

${ }^{68}$ Thomas, supra note 41 , at 128 ; Deroussin, supra note 40 , at $84-5$.

${ }^{69}$ For a similar account of this evolution, see Austin, supra note 62, at 353.

${ }^{70}$ Arendt, supra note 62, at 102; Agamben, supra note 62; Thomas, supra note 41.
} 


\section{Three Consequences of the Disjunction Between Persona and Homo}

Three aspects of the Roman understanding of legal personality stand out in the context of legal debates about biomedical issues: (1) the relation between legal persons and their bodies, (2) the temporal boundaries of legal personality, and (3) the relation between legal subject and legal order which is reflected in the legal category of the person.

\section{The Legal Person as a Bodiless Entity}

The legal person within the Roman tradition is essentially a bodiless entity. The physical does not fit well into the picture of the person when the latter is viewed merely as a legaltechnical abstraction and fiction. This absence of the human body can be understood as part of a more general tendency in the history of law to relegate the physical aspects of life from the legal realm. Interestingly, according to legal historian Jean-Pierre Baud, it was especially the classical and late Roman concept of the legal person that set into motion a long period of "disincarnation of law."

Similarly, modern legal doctrine often views the person in law as an empty and neutral category, ${ }^{72}$ an empty slot, ${ }^{73}$ or a mold that can hold whatever contents the legal order deems appropriate at that specific time and place. Artificial legal persons such as corporations clearly offer the best example in contemporary law of this legal category's bodiless character. In the future, however, other entities may also fill the legal mold of personality.

\section{The Fictional Temporal Boundaries of Legal Personality}

The Roman concept of persona also offers a striking illustration of the differences between the constructed, statutory temporality of our legal lives on the one hand, and the biological and biographical temporality of our actual lives on the other. ${ }^{74}$ According to Tur, the fact that within Roman law one individual could have various personae throws light on the peculiar temporal boundaries that characterize the legal person:

When I ask my students, 'What did Romans have in common with cats?', the answer I seek, but very rarely get, is that both have many lives.... There was in

\footnotetext{
71 'Désincarnation du droit.' See Jean-Pierre Baud, L’Affaire de la Main Volée. Une Histolre JuRidique du Corps 47 (1993).

72 Thomas, supra note 38, at 104.

${ }^{73}$ Tur, supra note 44 , at 121 .

${ }^{74}$ Thomas, supra note 41 , at 136.
} 
Roman law no one-to-one relationship between the physical being and that physical being's legal life or lives. Thus, while it is often thought that the legal life of an individual is in some sense natural ... even the legal life of a human being is artificial in the sense that it need not ... stand in a one-to-one relationship with his physical life .... In Roman law, human beings had legal lives that started and stopped during their natural lifetimes. $^{75}$

Indeed, legal history provides us with various examples to illustrate that legal life does not have to begin and end with birth and death. From a strictly legal-technical perspective, there are no fundamental objections to the use of legal fictions to determine the beginning and ending of legal personality. For example, according to the Roman nasciturus fiction, ${ }^{76}$ which is still recognized in many legal systems, a fetus in utero is considered already born whenever that is to the child's advantage; for instance, with regard to inheritance. As to the ending of legal personality, the legal figures of homo sacer, ${ }^{77}$ mort civile (civil death), and outlawry offer historical examples of discrepancies between legal and biological death.

\section{Legal Personality as a Role That Can be Rewritten}

Finally, the partially Roman origins of the current conception of legal personality demonstrate that ultimately, the legal person is a representation of the individual within the confines of the law. As such, legal personality operates as a reflection of the relation between legal subject and legal order. From this point of view, legal subjectivity is not a reflection of one's concrete, natural self, nor is it a natural attribute which befalls one automatically with birth, as is solemnly stated in the recitals of human rights declarations and conventions. Instead, as persona's etymological roots in Roman theatre also show, the conferral of legal personality, like the civil status that is connected to it, can be compared to a role or mask, developed by the law for its subjects to play on the legal stage. This also means, however, that the role can be rewritten or a different mask may be chosen at any given time.

Interestingly, these three characteristics of the Roman concept of persona correspond with three possible types of artificialization of legal personality that can be recognized within

\footnotetext{
75 Tur, supra note 44 , at $117-18$.

76 “Nasciturus pro iam nato habetur, quotiens de commodis eius agitur." (D 1.5.7).

77 For an analysis of the concept homo sacer in the light of current biopolitical strategies in law, see GIorgio AgAmben, Homo SACER: SOVEREIgn POWER AND BARE LIFE (1998) which explains that the term homo sacer is a figure of Roman law that signifies a person who is banned and may be killed by anybody without punishment, but who may not be sacrificed.
} 
the current calls for a more fluid, hybrid, chimeric and plastic account of the natural person. The separation of person and body corresponds with the proposed disembodiment of the natural person; the fictional temporal boundaries of persona point in the direction of fictionalization of the natural person; and, lastly, the account of persona as a role or mask opens the way for a more individualized account of the legal concept of the person, resulting in a fragmentation of the natural person. In the next three sections, these three forms of artificialization will be critically examined, starting with the tendency towards disembodiment. As will be argued, each of these approaches falls short to explain the complexities involved in locating our human, embodied natures in biomedical law.

\section{Disembodiment: The Legal-Technical Separation of Person and Body}

The first implication of the artificialistic disjunction between persona and homo is the disembodiment of the legal person. Tellingly, the artificial nature of legal personality leads some legal scholars to conclude that "the embodiment of man is for his legal personality a completely irrelevant feature." 78 This should not, however, be taken to mean that the body is necessarily absent in the legal-technical framework. What it does mean is that in this legal approach, the body can be represented only as separate from and ancillary to the legal person, as a physical superfluum ${ }^{79}$-and not as an integral part of the person. In other words, from this dualistic perspective, the human body can only be viewed as an object of rights (res), rather than as part of the legal subject (persona). ${ }^{80}$

This separation of person and body, which follows from the strictly legal-technical understanding of the natural person, would seem to correspond with the technological separation of person and body in biomedical contexts. As biomedical technologies have brought the possibilities to isolate, conserve, and transfer human body parts and materials to a new level, so, too, have they subsequently created the conditions under which the human body can, in theory, be perceived as an object of property law and thus as separate from the person owning this body. One would consequently expect the artificialistic, legaltechnical conception of personality to be dominant in this field.

\section{Biolaw's Naturalization of the Legal Person}

Yet, legal systems have responded more ambiguously to the emergence of biomedical technologies. Although biomedical technologies radically challenge the naturalistic premises of law's natural person, law continues to refer to the lived reality of the human

\footnotetext{
78 "Die Leiblichkeit des Menschen ist für seine Persönlichkeit eine ganz irrelevante Eigenschaft." See ERNST ZITELMANN, BEgRIFF UND WESEN DER SOGENANNTEN JURISTISCHEN PERSONEN 68 (1873).

${ }^{79}$ Gray, supra note 58 , at 28 (citing Meurer).

${ }^{80}$ See Baud, supra note 71; see also Deroussin, supra note 40.
} 
body and to human life in its biological dimensions. In fact, the biomedical artificialization of human life has also led, somewhat paradoxically, to a renewed naturalization of law's person. This can be explained by a closer examination of the struggles within biolaw to represent the human body.

To establish a legal framework for biomedical developments, the physical realities of life must be captured, to a certain extent, in legal language. This process has so far proven to be challenging, with most of these "objects" of human origin defying existing legal categories: They go beyond the summa divisio of person and thing that runs through the entire system of law. ${ }^{81}$ In some cases, human biological materials are represented in law as being distinct from their donors. The European Regulation on Advanced Therapy Medicinal Products $^{82}$ illustrates, for instance, how the allocation of medical products of human biological origin is now governed largely by internal market law. According to this logic, once human biological materials have been donated and transformed into advanced therapies, they can primarily be qualified as the object of property rights. In this context, a legal-technical account of the person will, to a large extent, suffice.

In other cases, however, the legal ties between person and body have not been severed. In most legal systems, for example, the general rule is that there is no property in the body and its parts. ${ }^{83} \mathrm{~A}$ clear indication of this is the widely recognized legal principle of noncommercialization, according to which elements of the human body cannot give rise to financial gain for the donor. ${ }^{84}$ The main reason for the special legal status of human body parts and materials is that, even if it is technologically possible to alienate and transfer these materials, they remain connected to the person in genetic, cultural-symbolic, but also legal ways. ${ }^{85}$

To bring this connection between the body and the person to legal expression, an embodied, more naturalist account of the legal person is necessary. Consequently, the

81 See, e.g., Donna Dickenson, Property in the Body: Feminist Perspectives 1-25 (CUP 2007); Muireann Quigley, Property in Human Biomaterials-Separating Persons and Things?, 32 OXFORD J. OF LEGAL STUD., 659 (2012).

82 Council Regulation 1394/2007 on advanced therapy medicinal products and amending Directive 2001/83/EC and Regulation (EC) No 726/2004 2007, Nov. 13, 2007 O.J. (L 324) 121.

83 See, e.g., Jesse Wall, The Legal Status of Body Parts: A Framework, 31 Oxford J. LeGAL STUd. 783 (2011); Dickenson, supra note 81; Radhika Rao, Genes and Spleens: Property, Contract, or Privacy Rights in the Human Body?, 35 J. L. \& MED. ETHICS 371 (2007).

84 See, e.g., Convention of Human Rights and Biomedicine, art. 21, Apr. 4, 1997; art. 12 Council Directive 2004/23/EC on setting standards of quality and safety for the donation, procurement, testing, processing, preservation, storage and distribution of human tissues and cells, March 31, 2004, 2004 O.J. (L 102) 48.

85 Dickenson, supra note 81; Alastair V. CAmpBell, The Body in Bioethics (2009); Jesse Wall, The Trespasses of Property Law, 40 J. MED. ETHICS 21 (2014); Charles Foster, Dignity and the Use of Body Parts, 40 J. MED. ETHICS 44 (2014); Rao, supra note 83. 
biomedical artificialization of human life has, despite first appearances, also led to a renewed naturalization of law's person. In response to the spectacular rise of new medical technologies and their accompanying legal regimes, an accelerated process of "embodiment" of the legal subject is taking place: The natural person is becoming endowed with a legal body, of which human blood, genes, organs, bones, and gametes are already part.

Moreover, human dignity has emerged as one of the central principles in the juridification of the human body. The importance of human dignity for a legal understanding of the human body is illustrated by the first chapter of the EU's Charter of Fundamental Rights, which is entitled "Dignity." As well as the general right to human dignity (Article 1), this chapter brings together the right to life (Article 2), the right to physical and mental integrity (Article 3 ), the prohibition of torture and inhuman or degrading treatment or punishment (Article 4), and, lastly, the prohibition of slavery and forced labor (Article 5). What connects these various fundamental rights is that each relates to the protection of physical and biological aspects of life. More specifically, each of these rights depicts the human body as a fundamental part of one's personality and humanity. It is precisely this symbolic unity and interconnectedness of person and body that can be identified as the underlying thought of the legal principle of human dignity. ${ }^{86}$

This reading explains how the legal principle of human dignity has become of central importance to biolaw. The unity of person and body functions as a normative view of mankind within the legal regulation of new technologies which may ultimately affect the human condition. Thus, within this field, human dignity is not understood solely as the underlying principle of human rights, but is also mobilized as a legal norm in its own right. ${ }^{87}$

In this elevation of human dignity to one of the central legal standards of biolaw, the transformation of law's person from norm addressee into independent legal norm is slowly becoming visible. This is because human dignity can be understood as a normative depiction of what it means to be a human person. As a result, the legal concept of the person is currently becoming so substantial and so full of content that it no longer functions solely as the subject of rights, but is also starting to have an effect on the demarcation and interpretation of those rights themselves.

\footnotetext{
${ }^{86}$ See also Britta van Beers, Luigi Corrias \& Wouter Werner, Probing the Boundaries of Humanity, in HumANITY ACROSS INTERNATIONAL LAW AND BIOLAW 11-12 (Britta van Beers, Luigi Corrias, \& Wouter Werner eds., 2014).

87 Deryck BeyleVeld \& Roger Brownsword, human Dignity in Bioethics and Biolaw (2001); Van Beers, Corrias \& Werner, supra note 86; ChARLES Foster, HUMAN DIGNITY IN BIOETHICS AND LAW (2011); Christopher McCrudden, In Pursuit of Human Dignity: An Introduction to Current Debates, in UNDERSTANDING HUMAN DIGNITY 3 (Christopher McCrudden ed., 2013).
} 


\section{The Biolegal Person as a Hybrid of Persona and Homo}

Admittedly, the naturalistic account of biolaw's person also has its weaknesses. First, the biolegal naturalization of the legal subject through the concept of human dignity has been contested from the start. Controversially, human dignity's implicit norm can also imply certain limitations as to what one can do with one's own body or reproduction-as the current prohibitions on human germline genetic engineering and organ selling demonstrate. In reaction, some authors have contested such biolegal provisions by appealing to alternative readings of human dignity that stress the importance of autonomy. The resulting conflicting interpretations of human dignity have been described in various ways in the academic literature, such as empowerment versus constraint, ${ }^{88}$ as the individual versus the collective dimension, ${ }^{89}$ and as rights-supporting versus rightsconstraining. ${ }^{90}$ Each of these pairs lays bare the inherent tensions in this essentially contested concept, thereby fueling further critique of the concept.

Second, the rebirth of human dignity in biolaw tells only one side of the story. Because human biological materials can vary from hair and nails to organs and gametes, the law has come up with a myriad of legal constructions and ingenious intermixtures of persons and things, as well as law and biology, to represent the new biomedical realities in law. In some contexts, classic property approaches to the human body will be more adequate, while in other contexts the legal interconnectedness of person and body will be emphasized. During this process, artificialistic and naturalistic visions of the natural person blend in new ways. As such, the legal struggle to come to an understanding of the human body demonstrates, in the words of British legal scholars Herring and Chau, that "the meaning and understanding of the self is a concept that cannot be fully captured by a single concept or approach." ${ }^{91}$

Nonetheless, it is clear from the outset that the resulting complexities of the relationship between law's person and the human body cannot be grasped, without distortion, from a purely artificialistic or legal-technical perspective. A naturalistic account of the legal person is equally necessary to bring into view the various connections established in biolawbetween law's person and the biological dimensions of life, between persona and homoespecially given that the artificialistic lens will filter away any reference to the physical world as a violation of the inherent purity and autonomous logic of the legal system.

\footnotetext{
${ }^{88}$ Beyleveld \& Brownsword, supra note 87.

${ }^{89}$ Roberto Andorno, Human Dignity and Human Rights as a Common Ground for a Global Bioethics, 34 J. MED. \& PHIL. 223 (2009).

${ }^{90}$ Christopher McCrudden, Human Dignity and Judicial Interpretation of Human Rights, 19 EUR. J. INT'L L. 702 (2008).

${ }^{91}$ Jonathan Herring \& P.-L. Chau, My Body, Your Body, Our Bodies, 15 Med. L. Rev. 60 (2007).
} 
More importantly, if the legal-technical account of law's person is nevertheless used in biomedical regulation, the outcome will inevitably and directly contradict the nominalist spirit of this approach. As argued, the artificialistic concept of legal personality can represent the human body only as a separate and alienable object. Regardless of its validity, such a Cartesian approach undeniably introduces a set of metaphysical presumptions into the supposedly "empty" category of legal personality. This is at odds with the anti-metaphysical premises of the artificialistic approach. This contradictory outcome reveals that the legal-technical category of the person is essentially not designed to arrive at a legal understanding of the relationship between person and body.

\section{E. Fictionalization: The Use of Legal Fictions at the Start and End of Life}

The second shape which the artificialization of the natural person can take on, based on the earlier analysis of the concept of persona in Roman law, is a contestation and fictionalization of the natural person's temporal boundaries. The remarkable temporal outlines of the legal person in Roman law have acquired new meaning and relevance against the background of new medical technologies. In this manner, within the complex medical practices surrounding organ transplantation and ARTs, the beginning and ending of legal personality are no longer a static given, but have instead become subject to renegotiation, as already mentioned. In reaction to these shifting realities and complexities, new legal fictions have been introduced that tinker with law's representation of the biological boundaries of life. To explain both the novelty and problematic nature of these biolegal fictions, more needs to be said about the nature and function of legal fictions in general.

\section{Fictio Legis}

As mentioned earlier, the peculiarities of law's account of the person have led some authors to refer not just to artificial personality, but also to natural personality as a legaltechnical fiction. ${ }^{92}$ Legal fictions are the most striking example of law's capacity to bend the truth for its own purposes. They can be defined as openly false statements in law, or as false statements that serve a certain legal purpose..$^{93}$ In a way, the use of fictions in law results from "willing suspension of disbelief," 94 to use Coleridge's famous definition of literary fiction. As "conceits of the legal imagination"

\footnotetext{
92 See Fagundes, supra note 4; see also Fuller, supra note 60, at 377; and Naffine, supra note 30.

${ }^{93}$ Fuller, supra note 60, at 369.

94 Willem J. Witteveen, De Retoriek in het Recht. Over Retorica en Interpretatie, StaAtsrecht en Democratie 409 (1988).

${ }^{95}$ Fuller, supra note 60, at 363.
} 
nominalist dimensions. The aforementioned nasciturus fiction, for instance, is clearly not meant to deceive anyone about the child's actual date of birth, but rather to enable the child, once he or she is born, to retroactively enjoy certain benefits. Similarly, corporate personality is often regarded as a legal fiction because its purpose is not to mask the differences between actual persons and corporations, but instead to offer an efficient way for some of the rules pertaining to natural persons to also apply to corporations.

The emergence of new legal fictions, and the re-emergence of old ones, in the rapidly developing area of medical law underline Fuller's claim "that the age of the legal fiction is not over." ${ }^{\prime 96}$ These legal-medical fictions also illustrate the view that "the fiction is generally the product of the law's struggles with new problems." ${ }^{\prime 97}$ In those cases, legal fictions can offer a smooth transition from the old to the new situation, without requiring the development of an entirely new legal framework. Correspondingly, new legal fictions have been called into existence to establish a legal understanding of the shifting boundaries of birth and death in the new contexts of organ transplantation and ARTs. However, the use of fictions in these areas comes at a certain price. The legal fictionalization of the ending of life will first be analyzed, followed by an examination of new legal fictions at the beginning of life.

\section{The Fictionalization of Death in the Practice of Post-Mortem Organ Procurement}

The technological possibility of postmortem organ procurement confronts legal orders with the question of how to facilitate organ removal at a sufficiently early stage without violating the "dead donor rule." Under this rule, vital organs can be removed only after the patient's death, and thus cannot be the cause of death. As is commonly known, the solution found for this problem has been to create new legal definitions of death, the best known of which is brain death. In earlier times, death was determined exclusively by verifying that the body had no pulse, was cold to the touch, and was without breath. If transplant surgeons had to wait until this stage, however, most organs would already be damaged before transplantation. The concept of brain death consequently offers a solution by redefining death as the irreversible cessation of all brain functions. Without this redefinition, the removal of organs in such contexts would amount to murder.

More recently, a new definition of death has emerged in cases of so-called controlled donation after circulatory determination of death (“cDCDD"). In this practice, lifesustaining support is withdrawn when further treatment is deemed pointless. After circulatory functions such as breathing and pulse have ceased, surgeons will wait a certain time to ensure that the patient's death is irreversible before starting organ retrieval. Surgeons, however, need to procure the organs as soon as possible for the transplantation

${ }^{96}$ Lon L. Fuller, Legal Fictions: Third Installment, 25 U. ILL. L. REV. 878 (1930-1931).

${ }^{97} / d$. 
to be successful. Although medical protocols have solved this tension by requiring an interval between the cessation of circulatory functions and organ procurement, in practice physicians actually have a certain discretionary power. The interval between cessation of circulatory functions and organ procurement is sometimes so short that questions have arisen as to whether death in these cases is truly irreversible. The most striking illustration is heart procurement from non-heart beating patients, ${ }^{98}$ which seems, in itself, a contradictio in terminis.

To some, post-mortem organ procurement practices may appear to entail a minor legal shift in the definition of death by taking an alternative and earlier biological event as its basis. Yet, in various respects, it makes more sense to view these new definitions of death as unacknowledged legal fictions, as Shah, Truog, and Miller convincingly argue in a recent series of articles. ${ }^{99}$ As they see it, brain death and the concept of death in CDDCD cases are both so far removed from ordinary biological and legal understandings of death, that it is better to be explicit about the artificiality of these legal constructions by calling them what they are: legal fictions.

For example, some brain-dead patients maintain integrative functioning for several years. ${ }^{100}$ As to $\mathrm{cDCDD}$, some medical interventions to preserve organs may actually hasten death. ${ }^{101}$ Moreover, if brain death were truly to offer a new biological definition of death, then it would have to be similarly endorsed in all contexts. In practice, however, physicians can decide not to use this concept. A good example of such a situation is the status of brain-dead pregnant women. In those cases, brain death cannot be the sole or decisive factor in deciding whether the pregnancy will be continued, as other interests will also weigh in. ${ }^{102}$ In this light, brain death can better be regarded as a so-called status fiction, as Shah and others argue, whereby medical professionals may, in their discretion, treat persons who are not dead as if they were already dead for organ donation purposes. ${ }^{103}$ In the practice of $C D C D D$, medical professionals rely on a different type of legal fiction; an anticipatory fiction, whereby surgeons are allowed to proceed as if death has already taken

\footnotetext{
98 A.L. Dalle Ave et al., An Analysis of Heart Donation After Circulatory Determination of Death, J. MED. ETHICS doi:10.1136/medethics-2015-103224 (2016).

${ }^{99}$ See Shah \& Miller, ibid; Seema K. Shah, Piercing the Veil: The Limits of Brain Death as a Legal Fiction, 48:2 U. OF MICH. J. L. REFORM 301 (2015); Robert D. Truog \& Frank G. Miller, Changing the Conversation about Brain Death, 14:8 AM. J. Bıоethics 9 (2014); Seema K. Shah, Frank G. Miller \& Robert D. Truog, Death and Legal Fictions, 37 J. MED. ETHICS 719 (2011).

${ }^{100}$ See D. Allan Shewmon, Brain Death - Can It Be Resuscitated?, 39(2) HASTINGS CENTER REPORT 18 (2009).

101 Shah \& Miller 2010, supra note 20, at 552.

102 For a more elaborate analysis of this situation, see Shah, supra note 101; Truog \& Miller, supra note 101.

103 Shah \& Miller, supra note 20 , at 562.
} 
place, even if circulatory death cannot, with certainty, be declared irreversible at the moment of procurement. ${ }^{104}$

If it is true that legal fictions are used to define death, this raises several important concerns. The American Presidential report Defining Death hints at these concerns by stating that the policy in these matters "must accurately reflect the social meaning of death and not constitute a mere legal fiction." 105 Shah and Miller argue that the main reason that new definitions of death are generally denied to be legal fictions-and instead presented as a reflection of social and biological meanings of death-is to take away the impression that this new approach has been devised exclusively to promote the practice of organ donation. ${ }^{106}$ Indeed, it could be argued that implicitly using a legal fiction in the context of organ donation obfuscates what may be actually happening: Organs are being procured from patients who are still alive at the moment of procurement, transgressing the dead donor rule.

Depending on one's ethical viewpoint, this abandonment of the dead donor rule is not necessarily problematic as the procedure may save the lives of others. For example, Shah, Truog, and Miller use their analysis to argue for an abandonment of the rule. This position, however, remains highly contested. Many authors continue to defend the rule that organs can only be procured from dead donors, and view recent developments in the field of postmortem organ procurement as a sign that the dead donor rule should be more carefully applied. More importantly, even if we agree that the end indeed justifies the means in the context of organ procurement, it would be preferable to know exactly what these means are. This would lead to more transparent and honest deliberations on an issue that touches upon fundamental questions of life and death.

\section{The Fictional Legal Subject of Wrongful Life Claims}

Legal fictions have also been introduced at the start of legal life, specifically within the regulation of ARTs. The welfare of future children has become one of the main principles in this field of law, ${ }^{107}$ with the underlying idea being that decisions made by prospective parents during pregnancy, or even before conception, may affect the interests of their future children. This concern can be recognized as one of the guiding thoughts in the UK

\footnotetext{
${ }^{104}$ Shah \& Miller, supra note 20, at 563-64.

105 President's Commission for the Study of Ethical Problems in Medicine and Biomedical and Behavioral Research,

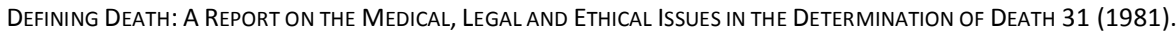

${ }^{106}$ Shah \& Miller, supra note 20, at 560.

107 See supra notes 18 and 19.
} 
Congenital Disabilities Act 1976, which made it possible for a child who is born disabled as the result of another's fault to claim compensation for the resulting disabilities. ${ }^{108}$

References to the welfare of future children in the context of ARTs can, however, lead to highly complex legal puzzles and, as shall be demonstrated, the creation of new legal fictions. These complexities have come to light specifically in legal systems, such as the Netherlands and several American states, that allow children resulting from ARTs to sue for wrongful life. ${ }^{109}$ Interestingly, these claims seem to have become possible also under English law since the 1990 amendments to the Congenital Disabilities Act. The English situation is used here to illustrate the legal fictions implied by wrongful life actions.

In 1990 the Human Fertilisation and Embryology Act (HFEA) extended the scope of the Congenital Disabilities Act to cover situations involving assisted reproduction, including pre-implantation genetic diagnosis (PGD). PGD involves selecting an embryo, based on genetic criteria, before it is implanted in the prospective mother's uterus. The resulting new section $1 \mathrm{~A}$ of the Act stipulates that, in cases of assisted reproduction in which an act or omission during selection causes disabilities, "the child's disabilities are to be regarded as damage resulting from the wrongful act of that person and actionable accordingly at the suit of the child." 110

Even if the 1990 introduction of section $1 \mathrm{~A}$ intended to put children born through ARTs on an equal footing with those born under natural circumstances, this new section has created the possibility-seemingly unintentionally-of wrongful life claims under English law. ${ }^{111}$ This is striking in the light of the well-known decision in McKay and Another v. Essex Area Health Authority, ${ }^{112}$ which explicitly held that wrongful life actions are unacceptable under English law.

The wrongful life action implicitly recognized in section $1 \mathrm{~A}$ allows children who are born disabled "from an act or omission in the course of the selection"113 the legal means to seek recourse for their disabilities. Remarkably, the child can claim damages for diseases that

\footnotetext{
108 In Section 1.1 of the Act.

${ }^{109}$ For an overview of wrongful life actions in several jurisdictions, see Ivo Giesen, The Use and Influence of Comparative Law in "Wrongful Life" Cases 8 UTRECHT L. REV. 35 (2012); and Ronen Perry, It's a Wonderful Life 93 CORNELL L. REV. 329 (2007).

${ }^{110}$ Section $1 \mathrm{~A}(1)(\mathrm{b})$.

111 See Rosamund Scott, Reconsidering "Wrongful Life" in England after Thirty Years: Legislative Mistakes and Unjustifiable Anomalies, 72 CAMBRIDGE L.J. 118-25 (2013).

112 McKay and Another v Essex Area Health Authority [1982] 1166 (QB); [1982] 2 All ER 771 (CA).

${ }^{113}$ Section $1 \mathrm{~A}(1)(\mathrm{b})$.
} 
were already present at conception and that are thus inherent to the child's existence. To put it differently, although the child could not have been born without these disabilities, section $1 \mathrm{~A}$ presents the latter as damage. It will probably not come as a surprise, then, that the legal construction that section $1 \mathrm{~A}$ introduces involves legal fictions pertaining to law's person on several levels. Even Tur-who describes legal personality as "wholly formal ... an empty slot that can be filled by anything that can have rights or duties"114admits to being troubled by the fictions underlying wrongful life claims. ${ }^{115}$

First, as children who sue for wrongful life are often also mentally disabled, it will usually be their parents who claim wrongful life on the children's behalf. Second, if the welfare of children is taken into consideration at this early stage, their legal interests precede their ascendance as legal subjects. It could consequently be claimed that the beginning of legal personality no longer coincides unambiguously with birth. The third and most remarkable legal fiction becomes evident if we focus on the damages awarded to children in wrongful life cases.

Two interpretations of damages in wrongful life claims first need to be distinguished. As the child's disabilities are inherent to his or her existence, a first possible approach is to award damages to the child for the fact of having been born. This seems to be the argumentation followed by the Dutch Supreme Court (Hoge Raad) in the Baby Kelly case. ${ }^{116}$ This approach is very controversial as, in this interpretation, the fact of being alive is indirectly presented as something for which one can be compensated. How can one have a right or legal interest to be aborted? Is this not at odds with the legal principle of human dignity? Moreover, how can one calculate the amount of damages to award, given that it seems impossible to compare the value of an existence with disabilities with the value of non-existence?

If, however, we take law's artificiality as a starting point, a different interpretation becomes possible, as legal scholar Rosamund Scott argues. From that perspective, awarding damages to the child for his or her entire life does not have to be interpreted to mean that the child, as he or she now is, would rather not live or not be born. Instead, this legal reasoning implies, in Scott's words:

[A] normative conception of harm in which a person is understood to be worse off in the world in which she is born than in the alternative world, where that alternative world is understood as an artefact or a

\footnotetext{
${ }^{114}$ Tur, supra note 44, at 121.

${ }^{115}$ Tur, supra note 44, at 126.

${ }^{116}$ HR 18 Maart 2005, NJ 2006, 606 m.nt. JBMV (Baby Kelly).
} 
construct, for the purpose of moral, and ultimately legal, reasoning. ${ }^{117}$

Oliver Wendell Holmes' famous phrase that "the life of the law has not been logic" could be used in Scott's defense. Nevertheless, the question remains as to whether these legaltechnical fabrications distract our attention from more vital questions, such as the question of whether certain lives can be deemed to be so unbearable that they can be perceived, from a legal perspective, as not worth living. Indeed, a large part of Scott's interesting analysis is focused on the question of which cases involve harm that is severe enough to qualify for a wrongful life action.

A second option is to hold the third party liable only for the child's disabilities. This approach is at the basis of section $1 \mathrm{~A}$ of the UK Act, and was also chosen by the French Cour de Cassation in its famous Perruche decision on wrongful life. ${ }^{118}$ This interpretation raises other concerns. As the disability is inherent to the child's existence, and only nature or a genetic predisposition could have caused it, holding third parties liable for this disability would seem to go against the "laws of nature." In other words, interpreting wrongful life claims in this way would seem to stretch the concept of legal causation to its limit.

More importantly, it creates a new legal fiction; that is, the fiction that the child could have been born without disabilities. In this interpretation, it is no longer a question of an alleged right or interest not to be born, which would seem to underlie the wrongful life claims in the first interpretation, but rather the right to be born in another body. As this construction fictionalizes the way the natural person relates to his or her body, it could be said that the result is not just a legal fiction, but an entirely fictional legal subject, as Yan Thomas argues in his eloquent analysis of the Perruche case. ${ }^{119}$

As such, this new legal fiction takes the artificiality of law's natural person to a whole new level. By recognizing wrongful life claims, children can legally contest the natural state in which they were born, thereby dissociating their legal selves from their embodied selves in a radically new way. Moreover, by exercising their right to be born in another body, these individuals retroactively create a legal persona that precedes their conception. ${ }^{120}$ The disjunction between legal and biological temporality, which, as we have seen, goes back to Roman law, is thereby brought to new heights.

\footnotetext{
117 Scott, supra note 111 , at 131.

${ }^{118}$ Cour de cassation [Cass.] [Supreme Court for Judicial Matters] ass. plen., Nov. 17, 2000, (Perruche), JCP 2000, II, 10438, 2293. This case law was overturned by the Patients' Rights and Quality of Care Act (2002). 
This section argued that the use of legal fictions at the start and end of life can have several adverse effects. The case of brain death shows that using legal fictions in questions of life and death, when these fictions remain unacknowledged, can serve to conceal vital arguments and considerations, such as the fact that the dead donor rule may actually be violated. In turn, the legal fictions that are employed in wrongful life cases radicalize the gap between legal and biological reality to such an extent that the natural self and legal self not only become dissociated, but even juxtaposed. Within this context the use of legal fictions rests on a negation of what is biologically possible. Does that offer a new illustration of the inherent artificiality of legal-technical reasoning? Or should one rather say, in Fuller's words, that "there are limits to the elasticity of even legal concepts?"121

\section{F. Fragmentation: The Natural Person as Causa Sui}

The wrongful life fiction, as identified in the previous section, illustrates how the disjunction between the legal person and its flesh-and-blood counterpart opens up the possibility for legal persons to use their legal subjectivity to contest the "natural" shape they take on in law, and claim the right to decide themselves how they are represented in the legal order. This section focuses on the related issue of the increasing numbers of individuals contesting the ways in which they are known and registered in the legal order. They are legal subjects claiming the right to dictate the terms of their own constitution. In other words, if legal personality can be viewed as the role that the law writes for its subjects to play on the legal stage, these individuals demand to be recognized as the authors or co-authors of their own roles. This brings into focus the last of the aforementioned three possible types of artificialization of the natural person: A personal customization and therefore fragmentation of natural personality.

\section{I. "The State Decides Who I Am"122}

Recent public debates-on the recognition of a third gender, new forms of parenthood, and the option to let individuals decide for themselves on the factors to be considered decisive in the ultimate determination of their death-illustrate how individuals can experience the naturalistic characteristics of their legal personalities as being restrictive of their rights and freedoms. Their question is, "Why should the state decide who I am?"123

In a way, these individuals remind one of the sailors on Neurath's boat who must reconstruct their ship on the open sea; they use their legal subjectivity to reshape the

\footnotetext{
${ }^{121}$ Fuller, supra note 60 , at 384.

122 See Amnesty International, supra note 27.

${ }^{123} / d$.
} 
conditions under which they are known as legal subjects. Although their quest is not logically impossible, it is also clear beforehand that there are certain limits to what aspects of their legal personality can be reconstructed and replaced in the process. If foundational categories of law, such as legal personality, become completely open to subjective interpretation by the legal subjects themselves, the legal system will become too singular and uneven to be able to guarantee legal certainty and equality before the law. The question is when the limit has been reached. Several recent illustrations of the claim to legally define oneself are discussed below in order to provide a tentative answer to that question.

The claim for legal autopoiesis can, firstly, be recognized in discussions on transsexuality. Naffine proposes, for example, to outlaw sexing altogether:

$[T]$ o be true to pure liberal individualism, the law might permit and enable self-ascribed sexing. This might entail a proliferation of sexes from which to choose or at least a third term .... We might choose to have a sex to express our individuality... or we might choose to have no sex at all. ${ }^{124}$

In other words, "the multiplicity and fluidity of legal identity"125 that characterizes the legal-technical understanding of the legal person should also be applied to gender. Similarly, Chau and Herring argue that "the law must cease to use sex as a legal category ... and should instead recognize a wide range of sexual identities" to do justice to the "complexity of every individual." ${ }^{26}$

The case of transsexuality shows how a legal-technical conception of the legal person can be mobilized for emancipatory goals, even if this overtly political agenda means that one is, strictly speaking, abandoning the legal-technical framework. In fact, self-ascribed sexing is close to becoming a legal reality in some legal systems. In Germany and the Netherlands, for example, the legal requirement of surgery as a pre-condition for recognizing one's new gender has recently been deemed a violation of the constitutional right to physical integrity. ${ }^{127}$ Physical criteria for legally establishing the new gender have therefore been abandoned. Instead, as with the UK Gender Recognition Act 2004, a permanent conviction

\footnotetext{
${ }^{124}$ Naffine, supra note 36 , at 641.

${ }^{125} / d$. at 642 .

${ }^{126}$ P.-L. Chau \& Jonathan Herring, Defining, Assigning and Designing Sex, 16 INT'L J. L., POL'Y \& THE FAM. 358 (2002).

127 For Germany, see Bundesverfassungsgericht [BVerfG] [Federal Constitutional Court], Jan. 11, 2011, 1 BvR 3295/07, NeUE JURISTISCHE WOCHENSCHRIFT [NJW] 909, paras. 70-71; for the Netherlands, see Transgenderwet 18 Dec. 2013 Stb. 2013.
} 
that one belongs to the other gender, with such conviction to be tested by a committee of experts, now constitutes sufficient grounds to have one's gender amended in the birth registries. Danish law took it one step further in 2014 by not even requiring evidence from experts for a new gender's legal recognition. ${ }^{128}$

\section{II. "Nobody Can Create Rights for Himself"129}

In the previous quote, Naffine describes her arguments as a logical application of liberal thought. Indeed, self-ascribed sexing can be interpreted as a liberalization of the gender difference, leaving it to the individual to decide where the boundary between the sexes is drawn. Notwithstanding the positive, emancipatory effects in the case of transsexuality, this logic of self-ascription has its limitations when applied to the legal concept of the person and its attributes. The risk is a somewhat radicalized reading of autonomy and individual rights, which neglects the institutional conditions under which one can become an autonomous subject in the first place. ${ }^{130}$

Interestingly, it is generally agreed, even within the artificialistic tradition, that there are limits to seeing the natural person as its own author, as causa sui. The partially Roman origins of the current conception of legal personality can be used, for example, to demonstrate that, ultimately, the legal order determines which entities count as legal subjects, as opposed to the legal subjects themselves.

The ambiguous meaning of the term "subject" is revelatory in that respect; as legal subjects, individuals are part of the legal order to which they are subjected, but which in its turn also constitutes them as autonomous subjects. ${ }^{131}$ This lays bare the following paradox of legal personality: Even though legal subjectivity enables one to perform legal action and, as such, constitutes one's legal autonomy and self-determination, the legal category of the person itself is necessarily predetermined by the legal order.

The paradox involved in the constitution of the legal subject reveals what Kelsen refers to as "an antagonism between the law as an objectively valid order, a system of binding norms (the objective law) and the subjective law (the right) as possessed by a subject."132 It is clear to him that "nobody can create rights for himself.... [T]he legal determination

\footnotetext{
${ }^{128}$ See E. Saner, 'Europe's Terrible Trans Rights Record: Will Denmark's New Law Spark Change?' The Guardian (Sept. 1. 2014), http://www.theguardian.com/society/shortcuts/2014/sep/01/europe-terrible-trans-rightsrecord-denmark-new-law. 
ultimately originates in the objective law and not in the legal subjects subordinated to it. Consequently there is no full self-determination even in private law." ${ }^{133}$

Therefore, even if law's person in the Roman and Kelsenian conception can function without a metaphysical, theological, or naturalistic substrate, it is still the product of a "higher," albeit secular, authority: The legal order. Consequently, there are certain logical limits to the freedom that legal subjects have to choose or appropriate their own masks for the legal stage. These masks reflect their ties to the legal order and are therefore essentially public. To borrow an intriguing phrase from Hannah Arendt, "Personality is anything but a private affair,"134 even on a legal level.

In that sense, the state inevitably defines, in some way or another, who we are for the law's purposes. As the historical example of slavery demonstrates, as well as the contemporary example of inter- and transsexuality, these definitions can be oppressive and exclusionary. It could be said, however, that allowing self-ascription on a large scale within the law of persons introduces "the illusion ... of an infinite multiplication of masks," as Agamben writes. ${ }^{135}$ This may lead to a shattering of the category of the legal person in multiple interpretations.

Moreover, opening other aspects of the law of persons to individual preferences could have far-reaching consequences. If, for instance, a contractualist logic were to be consistently applied to bioethical questions which touch upon the division between persons and thing, the result would be antithetical to the foundations of much biomedical legislation. Should we leave decisions on the fate of corpses, organs, and frozen embryos entirely to the individuals whose biological materials are involved? That would amount to a conception of these entities as objects of individual property rights.

Another illustration is offered by proposals to personalize the death standard in contemporary debates on organ donation. Ethicists Savulescu and Wilkinson, and legal scholar Bagheri argue that it is time to abandon the dead donor rule and instead to leave it up to individuals themselves to define what would constitute their deaths. ${ }^{136}$ Indeed, as they write, legal death is currently defined differently in each country. Why not think bioethical pluralism through more radically and make the death standard dependent on individual preferences? Even if, however, this would perhaps make organs more readily

\footnotetext{
${ }^{133} / d$. at $170-71$.

134 Hannah ARendt, Men in Dark Times 72 (1968).

${ }^{135}$ Agamben, supra note 62, at 53.

${ }_{136}$ Julian Savulescu \& Dominic Wilkinson, Death Fiction and Taking Organs from the Living, PRACTICAL ETHICS (Oct. 24, 2008), http://blog.practicalethics.ox.ac.uk/2008/10/death-fiction-and-taking-organs-from-the-living; Alireza Bagheri, Individual choice in the definition of death, J. L. MED. ETHICs 33: 146-49 (2007).
} 
available, this approach could also be regarded as a direct contradiction to the Hippocratic oath.

A final example is the way in which ARTs fundamentally challenge the traditional family structure through their multiplication of mothers and fathers. Who should decide what the relationship is between a child and his or her multiple parents? Should the traditional family law system, with its attribution of family statuses and establishment of kinship, be replaced by an intent-based parenthood system, in which filiation is the result of private contracts? ${ }^{137}$ It is highly questionable whether such a contractualization of family relations, which turns children into objects of contract law, would be in the child's best interest.

The ambition to abolish legal statuses and replace them with contracts and individual rights would seem, in the long run, a self-defeating project that ignores the vital importance of law's symbolic, constitutive, and expressive functions. ${ }^{138}$ More importantly, if the founding categories of law were open to subjective interpretation by the legal subjects themselves, the legal system would become too singular and uneven to be able to guarantee legal certainty and equality for the law. There is a limit, therefore, as to how much fragmentation a legal order can take.

\section{G. Conclusion: The Changing Nature of Law's Natural Persons}

Postmodern and poststructuralist philosophy in the 1960s and 1970s announced the death of the human subject. Now, a few decades later, new technologies have led to a more tangible dissolution and fragmentation of the human subject and the human body. The effects of this dissolution have also reached the legal order: Law's natural person now seems less natural and less coherent than ever. In that sense, the artificialization of human life is running parallel with the artificialization of law's natural person.

Each of the naturalistic premises of the natural person, such as the fact that the beginning and ending of legal personality coincide with birth and death, and that natural persons are either male or female, has become contested. Moreover, even if it is clear that the natural person is distinguished from the artificial person by its human and embodied nature, it is also clear that terms such as "human" and "embodied" have become shrouded in

\footnotetext{
137 For a recent overview and analysis of this discussion, see Yasmine Ergas, Babies without Borders: Human Rights, Human Dignity, and the Regulation of International Commercial Surrogacy, 27 EMORY INT'L L. REV. 138 (2013).

${ }^{138}$ For further reflection on the symbolic functions of legal personality, see SUPIOT, supra note 9; Pessers, supra note 9. For more general reflection on the symbolic functions of law in biomedical regulation, see SYMBOLIC Legislation TheORY AND DeVelopments IN BiolaW (Bart van Klink, Britta van Beers \& Lonneke Poort eds., 2016 and Britta van Beers, Is Europe 'Giving in to Baby Markets'? Reproductive Tourism in Europe and the Gradual Erosion of Existing Legal Limits to Reproductive Markets, MED. L. REV. 23(1), 103-34 (2015).
} 
controversy. Correspondingly, heated debates have emerged among legal scholars about human dignity and the status of the human body and derived materials.

Has the time now come, then, to declare the death of law's natural person? Should the natural person move over and make place for the inherently plastic and disembodied artificial person? According to several authors writing on the law of persons, a further artificialization of law's natural person-in the form of either a disembodiment, fictionalization or customization of this legal category-is indeed necessitated by the complexities, multiplicities, and fluid realities of life in a postmodern society. These authors stress, moreover, that a more artificial conception of the person is already latently present within law in the form of the Roman concept of persona. More generally, it is beyond doubt that law's natural person differs radically from real-life human beings and can be interpreted differently, depending on the legal situation. From that perspective, James Boyle is right by pointing out that "law - out of all the disciplines of market and societyhas been the only one with a postmodern subject."139

Nevertheless, this Article's main thesis is that law's category of the natural person still has its merits, not only despite current developments, but maybe even because of them. Without doubt, the legal nature of law's natural persons is no longer self-evident and is currently undergoing a period of vigorous change. Biomedical and other enhancement technologies have complicated and challenged the relationship between the legal person and its natural substrate. Moreover, the legal nature of the natural person is not set in stone, and has been subject to change already from its Roman origins. In that sense, the natural person necessarily remains a hybrid of artifice and nature, also in the era of biomedical technology. Whether these technologies will eradicate the naturalistic premises of law's natural person altogether, however, remains to be seen.

As this article discusses, recent arguments favoring of a more artificial concept of the person ignore the multiple ways in which law brings about hybrid constructions of artifice and nature. Moreover, mobilizing a strictly legal-technical and artificialistic approach to the legal person to resolve issues raised by new medical technologies can also lead to undesirable, extreme and contradictory outcomes. Especially in the case of the legal fiction of wrongful life, the artificial world of law is transformed into a dizzying legal hall of mirrors; the more we peer into it, the more we lose track of where our natural and artificial selves end, and where our legal selves begin. Law's person is then no longer the legal reflection of flesh-and-blood human beings; it is no longer even the reflection of a legal understanding of flesh-and-blood human beings. Instead, the legal person, in its radically artificialized version, seems to become a copy without original, a simulacrum. ${ }^{140}$

\footnotetext{
139 James Boyle, Is Subjectivity Possible? The Postmodern Subject in Legal Theory, 62 COLO. L. REV. 523 (1991).

140 See Gilles Deleuze, The Logic of SenSe 257 (1990). Deleuze gives the following definition of simulacrum:
} 
More generally, the answers offered by the artificialistic approach to law's person do not answer the most vital questions raised by biomedical technologies. It is all too easy to maintain that law is radically cut off from biological reality, or that individuals have the right to shape themselves as they want, in an era in which the human condition itself is becoming the object of technological interventions. On the contrary, emerging technologies such as artificial intelligence and medical biotechnology place the essentially contested concepts of humanity, human dignity and human nature back onto the legal agenda. No longer merely a bone of contention in the mainly theoretical debates between legal positivists and natural law thinkers, human nature has now become the focal point of heated political debates on the legal regulation of technologies that may actually affect the human condition. These questions are not of a merely legal-technical nature. Therefore, a strictly legal-technical concept of the person cannot suffice in the regulation of emerging technologies. Instead, what is needed is a legal concept of the person which can bring to expression what is, ultimately, at stake in the coming era of human enhancement technologies: Our embodied, human nature.

If we say of the simulacrum that it is a copy of a copy, an infinitely degraded icon, an infinitely loose resemblance, we then miss the essential, that is, the difference in nature between simulacrum and copy.... The copy is an image endowed with resemblance, the simulacrum is an image without resemblance. $I d$. 
